\title{
Contamination of the soil by eggs of geohelminths in rural areas of Lodz district (Poland)
}

\author{
J. BLASZKOWSKA ${ }^{1}$, P. KURNATOWSKI ${ }^{1}$, P. DAMIECKA ${ }^{2}$ \\ ${ }^{1}$ Department of Biology and Medical Parasitology, Medical University of Lodz, Poland, \\ E-mail: joanna.blaszkowska@umed.lodz.pl; ${ }^{2}$ Department of Clinical Diagnostics and Clinical Biochemistry, \\ Military Medical Academy (WAM) University Clinical Hospital No. 2 in Lodz, Poland
}

\begin{abstract}
Summary
Contamination of soil with helminth eggs in the samples of fields, kitchen gardens, yards and composts in rural areas of Lodz district (Poland) was investigated. In this study, helminth eggs were found in $60-100 \%$ of field samples, in $20-100 \%$ of yards samples, in $0-20 \%$ of kitchen gardens samples and in $10-100 \%$ of composts. The highest average density of helminth eggs in $100 \mathrm{~g}$ of soil was detected in composts (44.0), then fields (28.5) and yards (18.0). In samples taken from kitchen gardens the average density of eggs was $0.4 / 100 / \mathrm{g}$ of soil. The comparison of frequency of positive samples from fields, kitchen gardens and yards did not exhibit significant difference $(\mathrm{p}>0.05)$. The soil samples of fields contained mainly eggs of $A s-$ caris spp. (87.7\%), less frequently Toxocara spp. (7.7 \%) and Trichuris spp. (3.5\%). In samples from yards among detected eggs the most often were Toxocara spp. (73.9\%), and there were statistically significant differences in comparison with fields $(7.7 \%)$ and composts $(0.3 \%)$. The highest prevalence of eggs with moving larva was noted in yards $(25.6 \%)$, which differ statistically significantly from analogous value for fields $(\mathrm{p}<0.05)$ and composts $(\mathrm{p}<$ $0.0001)$.

These results showed a considerable infestation of soil with geohelminth eggs of the examined rural areas of Lodz district which is a potential source of antropozoonosis.
\end{abstract}

Keywords: Toxocara spp.; Ascaris spp.; geohelminths; soil contamination; organic composts

\section{Introduction}

Geohelminths are found worldwide and have a significant pathogenic effect both on people and animals. More than 2 billion people around the world are infected by these parasites. Ascaris spp. and Trichuris spp., intestinal nematodes of human or pig origin are still exceedingly common in many developing countries, in poor communities with insufficient water supply, inadequate sanitation and little health awareness. In contrast, they are rare in the developed countries, however a growing danger of contamination of human environment with infectious stages of Toxocara from dogs and cats can be noticed (Bethony et al., 2006; Brooker, 2010).

The soil-transmitted helminths (STH) are a group of parasitic nematode causing human infection through contact with parasite invasive eggs or larvae. Immature stages (eggs) require incubation in the soil before they become infective. Most often humans become infected by ingestion of infective form of geohelminths either from soil, raw fruit and vegetables, or dirty hands. STH infections affect most frequently children in both developing and developed countries and are associated with retarded growth, reduced physical activity and impaired learning ability (Drake et al., 2000). The existence of viable geohelminth eggs in superficial layer of soil presents a potential public health hazard, especially that these eggs are extremely resistant to adverse weather and chemical agents. Thus, soil contamination seems to be the most direct indicator of the risk of STH infection among human population. For this reason many studies have been carried out in recent years to determine the prevalence of geohelminth eggs in the soil of parks, playgrounds, sandpits, beaches, backyards and gardens, farmyard and other urban and rural areas. Toxocarosis is reported to be one of the most prevalent helminthiosis in industrialized countries (Magnaval et al., 2001). Soil sampling from urban environments shows widespread contamination of the public recreation areas in particular, with the eggs of Toxocara canis, and the contamination rate by ascarid eggs has been shown to range from 1 to $78 \%$ of soil samples throughout the world (Mizgajska, 1997; Matsuo \& Najashio, 2005; Dubná et al., 2008; Tavassoli et al., 2008; Klapec, 2009). The Toxocara spp. prevalence of samples from public parks in Ankara (Turkey) was estimated at $30.6 \%$ (Oge \& Oge, 2000) and 
that from sandpit samples in Toulouse (France) at $38 \%$ (Ferré \& Dorchies, 2000). Similarly high contamination rates of 64 and $67 \%$ were found in public playgrounds and parks of Ancona (Italy) (Giacometti et al., 2000) and Murcia (Spain) (de Ybanez et al., 2001). The study conducted in two cities of the Marche region of Italy revealed prevalence of $T$. canis eggs of $28 \%$ in faecal deposits collected in public green areas (Poglayen et al., 2000). A relatively small number of reports have focused on the infection risk of populations living in rural or suburban settings. The data published indicate that toxocariosis may be a problem not only for urban dwellers but also for rural inhabitants. A higher antibody prevalence in the rural population compared to the urban one was recorded in Ireland (Holland et al., 1995), in the Slovak Republic (Havasiova et al., 1993), in China (Luo et al., 1999), in the Czech Republic (Uhlikova \& Hubner, 1998) and in Poland (Borecka et al., 2010).

The use of wastewater, human and animal excreta in agriculture is a traditional and widespread practice in developing countries, but its use may have negative impact on human health (WHO, 2006). The main health risk associated with natural fertilizer use (mainly fresh or inadequately composted manure) is infection with intestinal nematodes, in particular infections with Ascaris spp. (Blumenthal et al., 2001; Amahmid \& Bouhoum, 2005; Trang et al., 2007). Agricultural use of natural manure must be designed for sanitization to reduce helminth eggs counts and viability, to meet the WHO nematode guideline of $<1$ viable egg/g total solids (WHO, 2006). Ascaris eggs are particularly important as indicator of the hygienic quality of natural compost. Among the pathogens of epidemiological factors, Ascaris eggs are the most resistant to liming, dewatering and high temperature. Their removal suggests that all other pathogens have also been inactivated (Gantzer et al., 2001). The epidemiological studies on geohelminth infections that have been undertaken all over the world show that in tropical climates predominant parasite is Ascaris lumbricoides (prevalence up to $91 \%$ ), followed by Trichuris trichiura (up to $72 \%$ ) and hookworm (up to $54 \%$ ) (Narain et al., 2000; Naish et al., 2004; Stotharda et al., 2009; Brooker, 2010).

In the world, especially in developing countries, uncontrolled use of natural manure (e.g. cowpat, water from sources contaminated with human and animal excrement) to fertilize vegetables and fruits has been reported to be responsible for their high rates of contamination with helminth eggs (Takayanagui et al., 2000; Ulukanligil et al., 2001). In Turkey, helminth eggs were detected in $12(5.9 \%)$ of 203 unwashed samples of raw vegetables from wholesalers in Ankara (Kozan et al., 2005) where Toxocara spp. (1.5\%), and Ascaris lumbricoides (1.0\%) eggs were found. These results highlight the potential for transmission of helminth eggs by unwashed salad vegetables and the importance of properly washing/disinfecting raw vegetables before consumption.

In Poland, like in other European countries, the sanitary condition of urban and country soil is not satisfactory and poses a serious epidemiological problem. In spite of improvement of sanitary conditions in the rural environment of Poland the spread of parasitic invasions is connected with incorrect composting of natural fertilizers with increased breeding rate, as well as numerous populations of domestic animals (dogs and cats). The study carried out in Poland revealed a higher level of infestation with Toxocara canis in the adult dogs from households in rural areas (34.2\%) (Borecka, 2005). Recently, a study has shown a high level of contamination of soil samples with Toxocara eggs from household environment of children with diagnosed toxocariosis in rural and urban areas of Lodz district (Borecka et al., 2010). Up till now in Lodz district no studies have been conducted to evaluate the extension of helminth contamination. Therefore we have undertaken studies aiming at evaluation of sanitary state of soil in rural areas of Lodz district. Taking into consideration the fact that such environment is a reservoir of numerous intestinal parasites the aim of the study was to look for development stages of geohelminths in the samples of fields, kitchen gardens, yards and composts.

\section{Material and Methods}

\section{Collection of soil samples}

Lodz is located in central Poland and has temperate climatic zone. Between March and May 2009, three different areas (fields, yards, kitchen gardens) in five villages (Ciosny, Grabina, Janow, Kolumna, Zapole) situated about 20 - $30 \mathrm{~km}$ of Lodz were examined. In those villages agricultural activities are mainly conducted on relatively small, family size farms which breed pig, cattle and poultry. Every farm keeps at least two dogs and $1-2$ cats. The ratio of dogs to inhabitants is $1: 3-4$ in those villages.

All examined fields were fertilized by liquid pig manure. They were situated near houses in a distance from 100 to 400 meters. Fields belonging to Ciosny village were fertilized with liquid pig manure originating from the same farms from which compost samples were taken.

Kitchen gardens, from which samples of soil were taken, were located outsider the yards around the houses. All were fenced; there was no access for domestic and feral animals. They were not fertilized with animal manure. All were fertilized with either vegetable compost or mineral fertilizer.

There were between two and five dogs in the farms where the samples were taken from yards. Most of dogs were kept in yards, in enclosure areas around family houses. The dogs were kept chained and set free evening and night-time only in nine farms. They could move free within a yard, even outside the household areas. There were domestic cats in most of the farms; semi-feral cats were in six farms.

One hundred fifty samples of soil were collected from above sites, fifty from fields, fifty from yards and fifty from kitchen gardens. Soil samples of about $300 \mathrm{ml}$ of total volume were picked from area $5 \mathrm{~m}^{2}$ in 9 various points from $3-\mathrm{cm}$ superficial layer of the ground. This is because geohelminth eggs do not penetrate the solid profile easily 
and stay for a long time near the surface. Soil samples were put into plastic bags labeled by number and description.

The studies also included examination of 40 samples from organic composts (plant with animal manure) from four villages: Bechcice (pig manure), Borkowice (pig mature and cattle manure in ratio 4:1), Ciosny (pig manure), Zapole (hen manure). Piles of compost were located outside the yards, inside farm premises. Not so far from them were places designated for collecting animal manure. In villages: Bechcice, Borkowice and Ciosny there was traditional pig farming with pigs in small piggeries (for $10-25$ pigs). Those pigs didn't have access to outdoor facilities. In those farms the pig faeces and effluents were removed either daily or every $2-3$ days. Pig manure the main component of organic compost was gained from piggery in late autumn (November/December 2008). Hen manure was collected in November 2008. For parasitological examinations 3 samples of composts (from bottom, medium and top layer) were taken; 3 samples, about $40 \mathrm{~g}$ from each layer were picked. Single samples collected from each compost where put in a container, which made about $300-$ $400 \mathrm{~g}$ of material designated for further sanitary evaluation.
Detection of eggs

The samples were examined in the laboratory immediately after drying at room temperature for $2-3$ days (depending on solid humidity). Samples were sifted through a 2-mm mesh sieve. Once dried, the soil samples were mixed and sifted to remove solid objects. Then, a 20 g portion was weighed and put into a $250 \mathrm{ml}$ Erlenmmayer's flask with a broad, smooth opening. The eggs of geohelminths were recovered by the flotation in saturated sodium nitrate (S.G. 1.30). All steps of extraction of geohelminth eggs from samples were used according to Mizgajska-Wiktor's technique (2005). After a final centrifugation cover slips were placed on the tubes and after a 5 min waiting period examined for the presence of eggs at 100x magnification. No attempt was made to differentiate between eggs of $T$. cati and T.canis, A. suum and A. lumbricoides, T. trichiura and $T$. suis and $T$. vulpis. In each sample, the number of eggs, their genus, stages of development and viability were determined by microscope. Immature eggs were kept in a glass chamber at temperature of $23^{\circ} \mathrm{C}$ and $100 \%$ relative humidity to observe whether the embryos would develop to larval stage. They were checked every 3 days for 4 weeks. Eggs with a moving larva were recognized to be potentially invasive.

Table 1. Contamination of soil and composts in rural areas with geohelminth eggs

\begin{tabular}{|c|c|c|c|c|c|c|c|}
\hline \multirow[t]{2}{*}{ Examined sites } & \multirow{2}{*}{$\begin{array}{c}\text { No. of } \\
\text { samples }\end{array}$} & \multirow{2}{*}{$\begin{array}{l}\text { Samples with } \\
\text { eggs }(\%)\end{array}$} & \multirow{2}{*}{$\begin{array}{c}\text { Total no. } \\
\text { of detected } \\
\text { eggs }\end{array}$} & \multirow{2}{*}{$\begin{array}{c}\text { No. of } \\
\text { eggs } / 100 \mathrm{~g}\end{array}$} & \multicolumn{3}{|c|}{$\begin{array}{l}\text { mean egg density per } \\
\text { positive sample }(20 \mathrm{~g})\end{array}$} \\
\hline & & & & & $\max$ & mean $\pm \mathrm{SD}$ & $\min$ \\
\hline Fields & 50 & $37(74)$ & 285 & 28.5 & 28 & $7.7 \pm 7.22$ & 1 \\
\hline Ciosny & 10 & $8(80)$ & 50 & 25 & 20 & $6.3 \pm 6.09$ & 2 \\
\hline Grabina & 10 & $7(70)$ & 30 & 15 & 10 & $4.3 \pm 2.63$ & 3 \\
\hline Janow & 10 & $6(60)$ & 16 & 8 & 7 & $2.7 \pm 2.25$ & 1 \\
\hline Kolumna & 10 & $10(100)$ & 164 & 82 & 28 & $16.4 \pm 7.04$ & 9 \\
\hline Zapole & 10 & $6(60)$ & 25 & 12.5 & 8 & $4.2 \pm 2.13$ & 2 \\
\hline Yards & 50 & $30(60)$ & 180 & 18 & 18 & $6.0 \pm 3.75$ & 1 \\
\hline Ciosny & 10 & $10(100)$ & 96 & 48 & 18 & $9.6 \pm 3.4$ & 6 \\
\hline Grabina & 10 & $2(20)$ & 6 & 3 & 4 & $3.0 \pm 1.41$ & 2 \\
\hline Janow & 10 & $7(70)$ & 38 & 19 & 10 & $5.4 \pm 2.87$ & 3 \\
\hline Kolumna & 10 & $4(40)$ & 8 & 4 & 4 & $2.0 \pm 1.41$ & 1 \\
\hline Zapole & 10 & $7(70)$ & 32 & 16 & 8 & $4.6 \pm 1.42$ & 3 \\
\hline Kitchen gardens & 50 & $2(4.0)$ & 4 & 0.4 & 3 & $2.0 \pm 1.41$ & 1 \\
\hline Ciosny & 10 & $0(0.0)$ & 0 & 0.0 & - & - & - \\
\hline Grabina & 10 & $0(0.0)$ & 0 & 0.0 & - & - & - \\
\hline Janow & 10 & $0(0.0)$ & 0 & 0.0 & - & - & - \\
\hline Kolumna & 10 & $2(20)$ & 4 & 2 & 3 & $2.0 \pm 1.41$ & 1 \\
\hline Zapole & 10 & $0(0.0)$ & 0 & 0.0 & - & - & - \\
\hline Composts & 40 & $21(53)$ & 352 & 44 & 50 & $16.8 \pm 12.93$ & 2 \\
\hline Bechcice & 10 & $10(100)$ & 284 & 142 & 50 & $28.4 \pm 14.03$ & 19 \\
\hline Borkowice & 10 & $4(40)$ & 18 & 9 & 8 & $4.5 \pm 2.52$ & 2 \\
\hline Ciosny & 10 & $6(60)$ & 48 & 24 & 12 & $8.0 \pm 2.83$ & 4 \\
\hline Zapole & 10 & $1(10)$ & 2 & 1 & 2 & $2.0 \pm 0.00$ & 2 \\
\hline
\end{tabular}




\section{Data analysis}

The differences in the rate of soil contamination between study sites and other data expressed as frequencies were estimated on the base of the $\chi^{2}$ test or Fisher's exact test. If any of the frequencies was less than 10 , Yates correction of continuity was applied. The non-parametric Mann-Whitney $U$-test was used to analyse the differences between the mean numbers of eggs in positive soil samples. Values of $\mathrm{p}<0.05$ were taken as significant.

\section{Results}

Our results showed a considerable infestation by geohelminth eggs of the examined fields, yards and composts in rural areas of Lodz district (Table 1). The comparison of frequency of positive samples from above sites did not exhibit significant difference $(\mathrm{p}>0.05)$. The highest average density of geohelminth eggs in $100 \mathrm{~g}$ of soil was detected in composts (44.0), then in fields (28.5) and yards (18.0). In samples taken from kitchen gardens only in Kolumna 4 Toxocara spp. eggs were detected (the average density of eggs - 0.4/100/g of soil) - Table 1 and Table 2 .

Among 50 samples from fields from 5 different villages, in 37 of them $(74.0 \%)$ helminth eggs were detected; the percentage of positive samples fluctuated between 60 and $100 \%$. Total number of detected eggs in microscope slides was 285 , and in positive samples the average density of eggs in $20 \mathrm{~g}$ was $7.7( \pm 7.2)$ - Table 1 . The majority of contaminated fields were found in Kolumna (100\% positive samples); mean egg density per positive samples was the highest $16.4( \pm 7.07)$. As seen in the results from data in Table 2, it was Ascaris spp. eggs that were most often detected (250 eggs in 50 samples). In Ciosny, 2 samples contained eggs, which were classified, according to morphological and biometric features to Strongyloides spp. Among 285 eggs detected in 37 samples $20 \%$ of them had potential for further development during incubation, and $16.8 \%$ of all detected eggs had reached full embryonic maturity (egg with moving larvae) - Table 3.

In yard samples, geohelminth eggs were detected and the prevalence of positive samples fluctuated between 20 and $100 \%$. Totally 180 eggs were obtained and the average density was $6.0( \pm 3.75)$ eggs $/ 20 \mathrm{~g}$. In samples from yards among detected eggs the most often were Toxocara spp., and there were statistically significant differences in comparison with other examined sites $(\mathrm{p}<0.0001)$. From 50 samples, $30(60 \%)$ contained 133 eggs of Toxocara spp. were detected (Table 1). In Ciosny Toxocara spp. eggs

Table 2. Genera of detected eggs of geohelminths in the samples of fields, yards and composts

\begin{tabular}{|c|c|c|c|c|c|}
\hline \multirow{2}{*}{ Examined sites } & \multirow{2}{*}{$\begin{array}{c}\text { Total no. } \\
\text { of } \\
\text { detected } \\
\text { eggs }\end{array}$} & \multicolumn{4}{|c|}{ No. of eggs $(\%)$} \\
\hline & & Ascaris & Trichuris & Toxocara & Other \\
\hline Fields & 285 & $250(87.7)$ & $10(3.5)$ & $22(7.7)$ & $3(1.1)$ \\
\hline Ciosny & 50 & $32(64)$ & $8(16)$ & $7(17)$ & $3(6)$ \\
\hline Grabina & 30 & $28(93)$ & $0(0.0)$ & $2(6.7)$ & $0(0.0)$ \\
\hline Janow & 16 & $16(100)$ & $0(0.0)$ & $0(0.0)$ & $0(0.0)$ \\
\hline Kolumna & 164 & $151(92.1)$ & $0(0.0)$ & $13(7.9)$ & $0(0.0)$ \\
\hline Zapole & 25 & $23(92)$ & $2(8.0)$ & $0(0.0)$ & $0(0.0)$ \\
\hline Yards & 180 & $9(5.0)$ & $5(2.8)$ & $133(73.9)$ & $33(18.3)$ \\
\hline Ciosny & 96 & $5(5.2)$ & $0(0.0)$ & $60(62.5)$ & $31(32.2)$ \\
\hline Grabina & 6 & $1(16.7)$ & $0(0.0)$ & $3(50)$ & $2(33.3)$ \\
\hline Janow & 38 & $0(0.0)$ & $0(0.0)$ & $38(100)$ & $0(0.0)$ \\
\hline Kolumna & 8 & $1(12.5)$ & $0(0.0)$ & $7(87.5)$ & $0(0.0)$ \\
\hline Zapole & 32 & $2(6.3)$ & $5(15.6)$ & $25(78.1)$ & $0(0.0)$ \\
\hline Kitchen gardens & 4 & $0(0.0)$ & $0(0.0)$ & $4(100)$ & $0(0.0)$ \\
\hline Ciosny & 0 & $0(0.0)$ & $0(0.0)$ & $0(0.0)$ & $0(0.0)$ \\
\hline Grabina & 0 & $0(0.0)$ & $0(0.0)$ & $0(0.0)$ & $0(0.0)$ \\
\hline Kolumna & 4 & $0(0.0)$ & $0(0.0)$ & $4(100)$ & $0(0.0)$ \\
\hline Janow & 0 & $0(0.0)$ & $0(0.0)$ & $0(0.0)$ & $0(0.0)$ \\
\hline Zapole & 0 & $0(0.0)$ & $0(0.0)$ & $0(0.0)$ & $0(0.0)$ \\
\hline Composts & 352 & $50(14.2)$ & $7(2.0)$ & $1(0.3)$ & $294(83.5)$ \\
\hline Bechcice & 284 & $1(0.4)$ & $0(0.0)$ & $0(0.0)$ & $283(99.6)$ \\
\hline Borkowice & 18 & $6(33.3)$ & $0(0.0)$ & $1(5.6)$ & $11(61.1)$ \\
\hline Ciosny & 48 & $41(85.4)$ & $7(14.6)$ & $0(0.0)$ & $0(0.0)$ \\
\hline Zapole & 2 & $2(100)$ & $0(0.0)$ & $0(0.0)$ & $0(0.0)$ \\
\hline
\end{tabular}


were detected in $100 \%$ of examined samples (total 60 eggs). In Ciosny and Grabina 33 eggs were isolated, which were classified as Ancylostoma caninum. These results indicate diverse soil contamination of yards with geohelminth eggs. The ability for further development was discovered in $30 \%$ of eggs, and $25.7 \%$ of them acquired invasiveness during the incubation period (Table 3 ).

Table 3. Viability of detected eggs of geohelminths

\begin{tabular}{lccc}
\hline Examined sites & $\begin{array}{c}\text { Total } \\
\text { no. of } \\
\text { eggs }\end{array}$ & $\begin{array}{c}\text { Viable } \\
\text { eggs } \\
(\%)\end{array}$ & $\begin{array}{c}\text { Eggs with } \\
\text { moving } \\
\text { larva } \\
(\%)\end{array}$ \\
\hline Fields & 285 & $57(20)$ & $48(16.8)$ \\
Kitchen gardens & 4 & $0(0.0)$ & $0(0.0)$ \\
Composts & 352 & $18(5.1)$ & $16(4.5)$ \\
Yards & 180 & $54(30)$ & $46(25.6)$ \\
\hline
\end{tabular}

The number of helminth eggs in samples from organic composts is shown in Table 1 . Positive were 21 compost samples $(53 \%)$ from among 40 which were taken from four villages. The average density of eggs was 44/100 $\mathrm{g}$ of compost. All (100\%) samples were positive and density of eggs was highest (142/100 g) in composts with pig manure in Bechcice village. In contrast in Zapole village in composts with hen manure positive samples were only in $10 \%$ of cases and only 2 eggs of Ascaris spp. were isolated Table 2. Among 352 eggs as many as 294 had biometric and morphological features of Strongyloides ransomi eggs. It should be emphasized that all detected eggs of $S$. ransomi contained non-viable larva. In microscope slides we also detected non-viable hatched larvae of this helminth. Eggs and infective larvae of this nematode are very sensitive to low temperature and low humidity. They are killed between 5 and 18 hours by temperature below $5{ }^{\circ} \mathrm{C}$ (Lucker, 1934; Tarczynski, 1956). The other isolated eggs were classified as Ascaris (in total 50 in 12 samples) and only in single samples as Trichuris spp. and Toxocara spp. - Table 2. It should be emphasized that only 18 (5.1\%) Ascaris spp. eggs detected in composts showed viability and $16(4.5 \%)$ of them achieved complete embryonic development (egg with moving larvae) - Table 3.

Statistically significant differences $(p<0.0001)$ were noted in viability of eggs detected in samples from fields, yards and composts. The highest prevalence of eggs with moving larva was noted in country yards $(25.6 \%)$, which differ statistically significantly from analogous value for fields $(\mathrm{p}<0.05)$ and composts $(\mathrm{p}<0.0001)$ - Table 3 .

\section{Discussion}

The contamination of soil with geohelminth eggs is a worldwide problem of public health (Nilanthi et al., 2003). For many years studies concerning this problem have been conducted. Geohelminths have life cycle closely related to the environment; invasive eggs are refractory to external factors so elimination of them is little effective. Parasitologists who perform helminthological examinations of soil samples receive varying results which is connected not only with the type of the material, but also with used methods. It should be emphasized that the techniques of eggs isolation from soil are not standardized (Oge \& Oge, 2000; Xavier et al., 2010). Our study concerning the assessment of contamination of soil with helminth developmental stages show that the degree of contaminations in selected rural areas of Lodz district (fields, yards and composts) is significant and consistent with other regions of Poland, which constitues a serious epidemiological problem. The obtained data are the first attempt at estimation of potential threat to the health of population of Lodz district. In presented study helminth eggs were found in $60-$ $100 \%$ of field samples, in $20-100 \%$ of yards samples and in $10-100 \%$ of composts. It should be noted that it is not possible to differentiate between eggs of the most common geohelminths, e.g. A. lumbricoides and A. suum, Toxocara cati and $T$. canis by means of morphology, as their eggs are rather identical. Accordingly, we did not provide information on the species of the geohelminth eggs found in the examined soil. Correct identification of geohelminth eggs of these species is possible only by using methods of molecular biology (Uga et al., 2000; Borecka, 2004; Borecka \& Gawor, 2008).

The results of presented study indicate that the use of animal manure is a source of contamination of agricultural soil by helminth eggs. In our study, the average density of eggs from field samples was 28/100 g. Most often Ascaris eggs were isolated; among 285 of detected eggs, as many as 250 were classified to this species. Among geohelminths, Ascaris eggs are the most refractory to unfavourable conditions during composting process. Since the $A s$ caris eggs shell consists of three basic layers - lipoidal inner layer, chitinous middle layer, and outer layer of protein (Wharton, 1980; Rojas-Valencia et al., 2004), the thick shell $(3-4 \mu \mathrm{m})$ can protect the eggs from a variety of chemical agents such as strong acids, strong bases oxidants, and synthetic detergents (Barrett, 1976; Orta de Velasquez et al., 2004). Unlike Ascaris eggs, Trichuris and Toxocara eggs exhibited a high level of resistance to high and low temperatures drying and disinfectants. The infective larvae remain protected within the highly resistant eggshell and as such can remain viable for many years in the environment. However, Strongyloides eggs have thinwalled eggshell and are highly sensitive to low temperature (below $5^{\circ} \mathrm{C}$ ), chemicals and drying (Lucker, 1934; Tarczynski, 1956).

Vegetables or fruit contaminated with Ascaris and Toxocara eggs represent important factors of transmission for rural and urban inhabitants (Vazquez Tsuji et al., 1997). In studies conducted by Ulukanligil et al. (2001) in Sanliurfa (Turkey) A. lumbricoides eggs were detected in $11.0 \%$ of unwashed vegetables tested. Choi and Lee (1972) found Ascaris eggs in $49.0 \%$ of 147 lettuce samples that were collected from markets in Taegu (Korea). Data from a 
recent study carried out in Ankara (Turkey) showed the presence of Toxocara eggs on $1.5 \%$ and Ascaris eggs on $1.0 \%$ of unwashed vegetables (Kozan et al., 2005). The liquid manure and other natural fertilizer used are implicated as a major route of direct contamination of fruit and vegetables with eggs of helminths (Stott et al., 1999). Moreover, kitchen gardens represent potential risk of toxocarosis as the consumption of raw vegetables from such localities is considered to be the cause of chronic low-dose infections (Magnaval et al., 2001). Our examinations of soil samples from kitchen gardens proved that fence them in effectively prevent soil contamination by intestinal parasite eggs of domestic animal. From 50 examined samples only two were positive and 4 eggs of Toxocara spp. were detected.

Major risk in agriculture is especially where untreated wastewater and excreta are used and sanitation standards are low (Capizzi-Banas et al., 2004; Kone et al., 2007). Hence, guidelines or standards on the hygienic quality of the biosolids or faecal sludge intended for agriculture use must be required. Many countries have enacted guidelines for the use and disposal of biosolids by adopting those of the United States Environmental Protection Agency (USEPA, 1993) which stipulate $<1$ viable helminth egg/4 g total solids (TS). According to the WHO guidelines 2006 for the safe manure, helminth eggs should be reduced to $\leq 1$ viable nematode egg/liter of treated wastewater or to $\leq 1$ viable nematode egg/g (TS) in compost used for vegetable fertilization (WHO, 2006). In Poland the condition for the use of organic fertilizers applied in growing vegetables and fruit for consumption by people is total absence of live helminth eggs from Ascaris, Trichuris and Toxocara (Ziomko, 2006). In samples taken from composts in Lodz district villages (Bechciece, Borkowice, Ciosny, Zapole) helminth eggs were detected and their density (average 44 eggs/100g), as well as species, depend on the type of manure used. In all villages composting was prepared in natural conditions - in outdoor piles over at least 3 months. In our study, samples of composts contained in total 50 eggs of Ascaris spp., 7 eggs of Trichuris spp. and 1 egg of Toxocara spp. and their viability was $5.1 \%$. The composts from Ciosny and Borkowice had viable Ascaris eggs, which did not meet the standards required for its use in growing vegetables and fruits. Also other investigators of composts produced on the basis of pig manure detected alive eggs of Ascaris spp. (15\%) and Trichuris spp. (8\%) (Ziomko, 2006). Moreover, in sewage deposits, Ascaris spp., Toxocara spp. and Trichuris spp. viable eggs were found (Sttot et al., 1999; Kone et al., 2007). It should be marked that incorrectly hygienized sewage deposits and composts (pasteurization, liming) play significant role in epidemiological chain invasions by geohelminthes in people and animals. Numerous cases of invasions caused by Ascaris suum and Trichuris suis in people were noted in spite of the fact that man is only an accidental host for them (Inatomi et al., 1999; Kakahara et al., 2004; Nejsum et al., 2005).

In our study, in compost samples from Bechcice and Bork- owice dead eggs and larvae of Strongyloides ransomi were detected. Up till now no case of contamination of man by $S$. ransomi has been noted which suggests that the presence of these eggs in external environment can be epidemiological threat only for animals. Studies of developmental cycle of $S$. ransomi (Lucker, 1934; Tarczynski, 1956) showed that eggs together with the pig faeces get into environment where hatch. In temperature $20-24{ }^{\circ} \mathrm{C}$ larva L2 hatch from egg after $4-18$ hours, and after 76 hours transform to larva infective L3. This maturation to infectivity is temperature dependent. The eggs and larvae of $S$. ransomi are destroyed between 5 and 18 hours by temperature below $5{ }^{\circ} \mathrm{C}$. It should be added that pig manure the main component of examined organic compost was gained from piggery in late autumn (November/December 2008). There was often critical temperature for S. ransomi eggs and larvae in piggeries. Moreover pig manure that was gradually removed from piggeries, was stored in piles outside where temperature at night was around $0{ }^{\circ} \mathrm{C}$. Therefore the conditions prevail in the piggeries as well during collecting of pig manure for compost could kill eggs or inhibit hatching of larvae and their development.

The soil contamination of public sites in urban and also rural areas by parasite eggs from pet or wild animals (Özkayhan, 2006; Rinaldi et al., 2006) can cause publichealth problems all over the world. Alarming is the high percentage of positive samples in soil and sand from European playgrounds and parks. $50 \%$ of positive samples were found in parks and sand pits in Utrecht (Holand) (Jansen et al., 1993), $62.6 \%$ of playground samples in Kirikkale (Turkey) (Özkayhan, 2006), $45 \%$ in parks in Prague (Czech Republic) (Dubná et al., 2008), 23 - $49 \%$ in recreation area and city backyards in three Polish cities (Poznan, Katowice, Cracow) (Mizgajska \& Luty, 1998; Mizgajska, 2000; Grygierczyk et al., 2003), $39 \%$ and $50 \%$ in holiday resort places in France (Ferré \& Dorchies, 2000; Beugnet \& Gadat, 1993), 87\% in the sand in children's playgrounds in Frankfurt (Duwel, 1984). A lower contamination $(1-8 \%)$ was seen in the playgrounds and parks in Sapporo City (Japan), Melbourne (Australia) and Urmia City (Iran) (Carden et al. 2003; Matsuo \& Najashio, 2005; Tavassoli et al., 2008), in public gardens in Resistencia city (Argentina), in public yards in Bangkok (Thailand) (Alonso et al., 2001; Wiwanitkit \& Waenlor, 2004). Seroprevalence rates reported in humans in different countries reflect the contamination of soil with Toxocara spp. eggs in urban and rural environments. Its prevalence in people ranges between $1-4 \%$ of adult population in Western Europe and $60 \%$ of children in developing countries (Obwaller et al., 1998). The exposure to Toxocara eggs seems to be higher in rural than in urban environment. The examination of central Poland areas revealed slightly higher prevalence of ground contamination with Toxocara eggs in rural $(27.5 \%)$ than in urban areas $(21.1 \%)$ (Gawor et al., 2008). Similarly in other countries, for example in Turkey, infection in rural areas was more prevalent (16.9\%) than in towns (1.4\%) (Dogan et al., 2006). Fillaux et al. (2007) mentioned three exposure parameters interacting 
with transmission of human toxocarosis, namely rural residence (common dog ownership and poor personal hygiene), socioeconomic status (poor sanitation level in disadvantaged areas) and favourable climatic conditions for embryonation and survival of Toxocara eggs (humid and warm climate). All quoted factors are involved in the epidemiology of human toxocarosis in Poland. Non-systematic deworming of dogs and cats, lack of birth control of feral or semi domestic animals may contribute to the high level of ground contamination in rural environment. In our investigations of yard samples a high percentage of soil contamination by eggs, mainly Toxocara spp. was observed; in $60 \%$ of positive samples 180 parasite eggs were detected, so the average density was $18 \mathrm{eggs} / 100 \mathrm{~g}$ of soil. These results are comparable with data obtained by Mizgajska-Wikor and Jarosz (2007) for farm yards in Wielkopolska, where the average density was 16.7 eggs/100 g of soil. High prevalence of Toxocara spp. eggs in villages was observed by Gundlach et al. (1996), Mizgajska and Luty (1998), Mizgajska (2000), Gawor and Borecka (2004). It should be emphasized that in our study $30 \%$ of isolated eggs of Toxocara spp., viable for development and invasiveness (eggs with moving larvae) were noted, so it confirms the fact that yards are the main reservoir of Toxocara spp. eggs in rural environment.

The samples were collected during spring-time, when according to many researchers the detection of geohelminth eggs is higher than in other periods of the year (Mizgajska, 2000). It is connected with high temperature and UV radiation during summer time and in case of Toxocara spp. also with reproductive period of hosts. From epidemiological point of view important is accumulation of geohelminth eggs on soil surface, and not their penetration into deeper layers. Observations which were conducted in natural conditions revealed that after one year eggs were found in superficial layer $(0-3 \mathrm{~cm})$, and cohesion of soil had no influence on their translocation (Mizgajska, 1997). In the spreading of parasite eggs take part earthworms, soil nematodes and snails which transport them from deeper layers to the surface. Szelagiwicz-Czosnek (1982) established that Ascaris suum when passing through earthworm alimentary tract are not damaged. Other investigations confirmed that geohelminth eggs are not inactivated in alimentary tract of Lumbricus terrestis, snails from Radix spp., or soil nematodes (Lysek, 1966; Mizgajska, 1993).

The presence of eggs in external environment is a risk to the health of man. So far no practical method of elimination of geohelminth eggs from soil had been found (Mun et al., 2009). The only method to reduce this risk is profilaxis consisting in veterinary monitoring of domestic animals population, deworming of dogs and cats and implementation of educational programs promoting hygiene in people. Epidemiological data show however that the effects of such measures are still unsatisfactory. Agricultural use of human and animal faeces is correlated with soil-transmited helminthosis (Naish et al., 2004; Trang et al., 2007; Yajima et al., 2009). The consumption of vegetables that are commonly fertilized with organic compost in the com- munity may lead to high infections rates with $A$. lumbricoides and $T$. trichiura. It should be remembered that geohelminth invasions belong to the disease of so the called "dirty hands", so observation of basic hygiene rules is of utmost importance in preventing invasions of these parasites in people. Also good sanitary condition of the soil is an effective and practical method against the spread of intestinal parasites among people. Parasitological estimation carried in selected rural areas of Lodz district indicates a considerable infestation of soil with geohelminth eggs which is a potential source of antropozoonosis.

\section{Acknowledgement}

The study was supported by the Medical University of Lodz from statutory fund-project no. 503-1013-1.

\section{References}

Alonso, J. M., Stein, M., Chamorro, M. C., Bojanich, M. V. (2001): Contamination of soils with eggs of Toxocara in a subtropical city in Argentina. J. Helminthol., 75: 165 - 168. DOI: $10.1079 / \mathrm{JOH} 200146$

Amahmid, O., Bouhoum, K. (2005): Assessment of the health hazards associated with wastewater reuse: transmission of geohelminthic infections (Marrakech, Morocco). Int. J. Environ. Health Res., 15: 127 - 133. DOI: 10.1080/ 09603120500062037

BARRETT, J. (1976): Studies on the induction of permeability in Ascaris lumbricoides eggs. Parasitology, 73: 109 - 121. DOI: 10.1017/S0031182000051374

Bethony, J., Brooker, S., Albonico, M., Geiger, S., LoukAs, A., Diemetr, D., Hotze, P.J. (2006): The solidtransmited helminth infections:ascariasis, trichuriasis, and hookworm. Lancet, 367: 1521 - 1532. DOI: 10.1016/S0140-6736(06)68653-4

Beugnet, F., GAdAT, R. (1993): Detection of Toxocara spp. ova and Ancylostoma spp. larvae in soil in Noumea, New Caledonia. Rev. Med. Vet., 144: 523 - 525

Blumenthal, U. J., Cifuentes, E., Bennett, S., Quigley, M., Ruiz-PALACIOS, G. (2001). The risk of enteric infections associated with wastewater reuse: the effect of season and degree of storage of wastewater. Trans. R. Soc. Trop. Med. Hyg., 95: $131-137$

BoreCKA, A. (2004): Differentiation of Toxocara spp. eggs isolated from the soil by PCR-linked RFLP. Helminthologia, 41: $185-187$

BORECKA, A. (2005): Prevalence of intestinal nematodes of dogs in the Warsaw area, Poland. Helminthologia, 42: $35-$ 39

BORECKA, A., GAWOR, J. (2008): Modification of gDNA extraction from soil for PCR designed for the routine examination of soil samples contaminated with Toxocara spp. eggs. J. Helminthol., 82: 119 - 122. DOI: 10.1017/ S0022149X07877522

BoreckA, A., GAWOR., NiEDWOROK, M., SORDYL, B. (2010). Occurrence of Toxoccara spp. eggs in household environment of children with diagnosed toxocarosis in 
Lodz voivodeship. Wiad. Parazytol., 56: 141 - 144

BROOKER, S., (2010): Estimating the global distribution and disease burden of intestine nematode infections: Adding up the numbers - A review. Int. J. Parasitol., 40: 1137 - 1144. DOI: 10.1016/j.ijpara.2010.04.004

CAPIZZi-BANas, S., Deloge, M., Remy, M., SCHWARTZBORD, J. (2004): Liming as an advanced treatment for sludge sanitisation helminth eggs elimination Ascaris eggs as model. Water Res., 38: 3250 - 3258. DOI: 10.1016/j.watres.2004.04.015

Carden, S. M., Meusemann, R., Walker, J., Stawell, R. J., Mackinnon, J. R., Smith, D., Stawell, A. M., HALL, A. J. (2003). Toxocara canis: egg presence in Melbourne parks and disease incidence in Victoria. Clin. Experiment. Ophthalmol., 31: 143 - 146. DOI: 10.1046/j.14 42-9071.2003.00622.x

de Ybanez, M. R. R., Garijo, M. M., Alonso, F. D. (2001): Prevalence and viability of eggs of Toxocara spp. and Toxascaris leonina in public parks in eastern Spain. J. Helminthol., 75: 169 - 173. DOI: 10.1079/JOH200164

CHOI, D. W., LEE, S. (1972): Incidence of parasites found on vegetables collected from markets and vegetable gardens in Taegu area. Korean J. Parasitol., 10: $44-51$

Dogan, N., Dinleyici, E. C., Bor, O., Töz O., ÖzBel, Y. (2007): Seroepidemiological survey for Toxocara canis infection in the northwestern part of Turkey. Türkiye Parazitol. Derg., 31: 288 - 291

Drake, L. J., JuKes, M. C. H., SternBerG, R. J., Bundy, D. A. P. (2000): Geohelminth infections (Ascariasis, Trichuriasis, and Hookworm): cognitive and developmental impacts. Sem. Pediatr. Infect. Dis., 11: 245 - 251. DOI: $10.1053 /$ spid.2000.9638

Dubná, S., LANGRovÁ, I., JaNkOVSKÁ, I., VADleJCh, J., PEKÁR, S., NÁPRAVNíK, J., FECHTNER, J. (2007): Contamination with Toxocara eggs in urban (Prague) and rural areas in the Czech Republic. Vet. Prasitol., 144: $81-86$. DOI: 10.1016/j.vetpar.2006.09.023

DuWEL, D. (1984): The prevalence of Toxocara eggs in the sand in children's playgrounds in Frankfurt. Ann. Trop. Med. Parasitol., 78: $633-636$

FERRÉ, P., DORCHIES, P. (2000): Prevalence of Toxocara eggs in sand pits in eight public parks in Toulouse. Rev. Med. Vet. 151: $501-506$

FillauX, J., Santillan, G., Magnaval, J. F., Jensen, O., LARrieU, E., Sobrino-BeCARIA, C. D. (2007): Epidemiology of toxocariasis in a steppe environment: the Patagonia study. Am. J. Trop. Med. Hyg., 76: $1144-1147$

Gantzer, C., Gaspard, P., Galvez, L., Huyard, A., Dumouthier, N., Schwartzbrod, J., (2001): Monitoring of bacteria and parasitological contamination during various treatment of sludge. Water Res., 35: 3763 - 3770. DOI: 10.1016/S0043-1354(01)00105-1

GAWOR, J., BORECKA, A. (2004): The contamination of the environment with Toxocara eggs in mazowieckie voivodship as a risk of toxocarosis in children. Wiad. Parazytol., 2004, 50: 237 - 241

GAwor, J., BoreckA, A., ZARnOwsKa, H., MARCZYNSKA, M., Dobosz, S. (2008): Environmental and personal risk factors for toxocariasis in children with diagnosed disease in urban and rural areas of central Poland. Vet. Parasitol., 155: 217 - 222. DOI: 10.1016/j.vetpar.2008.05.016

Giacometti, A., Cirioni, O., Fortuna, M., Osimani, P., Antonicelli, L., Del Prete, M. S., Riva, A., D’Errico, M. M., Petrelli, E., Scalise, G. (2000): Environmental and serological evidence for the presence of toxocariasis in the urban area of Ancona, Italy. Eur. J. Epidemiol., 16: 1023 - 1026. DOI: 10.1023/A:1010853124085

GrygierCZYK, D, KWIATKOWSKI, S., SADOWSKA, H. (2003): Soil contamination with Toxocara spp. eggs in the Katowice area and its environs. Wiad. Parazytol., 49: 57 60

Gundlach, J. L., Sadzikowski, A. B., TomczuK, K. (1996): Contamination of selected urban and rural environments with Toxocara eggs. Med. Wet., 52: 395 - 396

Havasiova, K., Dubinsky, P., Stefancikova, A. (1993): A seroepidemiological study of human Toxocara infection in the Slovak Republic. J. Helminthol., 67: $291-296$. DOI: $10.1017 / \mathrm{S} 0022149 \mathrm{X} 00013298$

Holland, C. V., Olorcain, P., Taylor, M. R. H., Kelly, A. (1995): Seroepidemiolgy of toxocariasis in school children. Parasitology, 110: 535 - 545. DOI: 10.1017/S0031 182000065252

InATOMi, Y., Murakami, T., TOKunaga, M., Ishiwata, K., NAWA, Y., UCHINO, M. (1999): Encephalopathy caused by visceral larva migrant due to Ascaris suum. J. Neurol. Sci., 164: 195 - 199

JANSEN, J., VAN KNAPEN, F., Schreurs, M., VAN WiJngAarden, T. (1993): Toxocara eggs in public parks and sand-boxes in Utrecht. Tijdschr. Diergeneesk., 118: $611-614$

KLAPEC, T. (2009): Contamination of soil with geohelminth eggs on vegetable organic farms in the Lublin voivodeship, Poland. Wiad. Parazytol., 55: 405 - 409

Kone, D., Cofie, O., ZurbrüGG, C., Gallizzi, K., Moser, M., Drescher, S., Strauss, S. (2007): Helminth eggs inactivation efficiency by faecal sludge dewatering and cocomposting in tropical climates. Water Res., 41: $4397-$ 402. DOI: 10.1016/j.watres.2007.06.024

Kakahara, K., Yoshimitsu, K., Ishigami, K., Irie, H., AIBE, H., TAJIMA, T. (2004): Liver lesions of visceral larva migrant due to Ascaris suum infection. Abdom. Imaging, 29: 598 - 602. DOI: 10.1007/s00261-003-0153-4

Kozan, E., Gonenc, B., Sarimehmetoglu, O., AyciceK, H. (2005): Prevalence of helminth eggs on raw vegetables used for salads. Food Contr., 16: 239 - 242. DOI: 10.1016/ j.foodcont.2004.02.005

LuO, Z. J., WANG, G. X., YANG, C. L., LuO, C. H., ChenG, S. W., LIAO, L. (1999): Detection of circulating antigens and antibodies in Toxocara canis infection among children in Chengdu, China. J. Parasitol., 85: $252-256$

LUCKER, J. T. (1934): Development of the swine nematode Strongyloides ransomi and the behavior of its infective larvae. US Dep. Agr. Tech. Bull., 437: 1 - 30

LYSEK, H. (1966): Study of biology of geohelminths. The influence of some geobionts on the epidemiology of geohelminthoses. Acta Univ. Palacki. Olomuc., 40: 75 - 81 
Magnaval J. F., Glickman L. T., Dorchies P., MoraSSIN B. (2001): Highlights of human toxocariasis. Korean J. Parasitol., 39: 1 - 11. DOI: 10.3347/kjp.2001.39.1.1

MAtsuO, J., NAKAshio, S. (2005): Prevalence of fecal contamination in sandpits in public parks in Sapporo City. Japan. Vet. Parasitol., 128: 115 - 119. DOI: 10.1016/ j.vetpar.2004.11.008

MizGAJSKA, H. (1993): The distribution and survival of eggs of Ascaris suum in six different natural soil profiles. Acta Parasitol., 38: 170 - 174

MizgajSKA, H. (1997): The role of some environmental factors in the contamination of soil with Toxocara spp. and other geohelminth eggs. Parasitol. Int., 46: 67 - 72. DOI: 10.1016/S1383-5769(97)00011-1

MizgAJSKA, H. (2000): Soil contamination with Toxocara spp. eggs in the Krakow area and two nearby villages. Wiad. Parazytol., 46: 105 - 1190

MizgajsKa, H., LuTY, T. (1998). Toxocarosis in dogs and contamination of soil with Toxocara spp. eggs in Poznan region. Przeglad Epidemiol., 52: 441 - 446

MizGAJSKA-WiKTOR, H. (2005): Recommended method for recovery of Toxocara and other geohelminth eggs from soil. Wiad. Parazytol., 51: 21 - 22

MizgajsKa-WiKTOR, H., JAROSZ, W. (2007): A comparison of soil contamination with Toxocara canis and Toxocara cati eggs in rural and urban areas of Wielkopolska district in 2000 - 2005. Wiad. Parazytol., 53: 219 - 225

Mun, S., Cho, S. H., KIM, T. S., OH, B. T., Yoon, J. (2009): Inactivation of Ascaris eggs in soil by microwave treatment compared to UV and ozone treatment. Chemosphere, 77: 285 - 290. DOI: 10.1016/j.chemosphere.2009.07.030

NAish, S., MCCARTHY, J., Williams, G. M. (2004): Prevalence, intensity and risk factor for soil-transmitted helminth infection in a South Indian Fishing village. Acta Trop., 91: 177 - 187. DOI: 10.1016/j.actatropica.2004.04.004

NARAin, K., RajgurU, S.K., Mahanta, J. (2000): Prevalence of Trichuris trichiura in relation to socio-economic and behavioral determinants of exposure to infection in rural. Assam. Indian J. Med. Res., 112: 140 - 146

Nejsum, P., PArker, E. D., Frydenberg, J., RoepstorfF, A., Boes, J., Haque, R. (2005): Ascariasis is a zoonosis in Denmark. J. Clin. Microbiol. 43: 1142 - 1148. DOI: 10.1128/JCM.43.3.1142-1148.2005

Nilanthi R. S, Brooker, S., Hotez, P. J., Montresor, A., ENGEls, D., SAVIOLI, L. (2003): Soil-transmitted helminth infections: updating the global picture. Trends Parasitol., 19: 547 - 551. DOI: 10.1016/j.pt.2003.10.002

Obwaller A., Jensen-Jarolim E., Auer H., Huber A. Q., KRAFT, D., ASPOCK H. (1998): Toxocara infestations in humans: symptomatic course of toxocariasis correlates significantly with levels of $\operatorname{IgE} / \mathrm{anti}-\mathrm{IgE}$ immune complexes. Parasite Immunol., 20: 311 - 317. DOI: 10.1046/j.1365-3024.1998.00146.x

Oge, S., Oge, H. (2000): Prevalence of Toxocara spp. eggs in the soil of public parks in Ankara. Turkey. Dtsch. Tierarztl.Wochenschr., 107: $72-75$

Orta de Velasquez, M. T., Martinez, J. L., MonjeRAMiREZ, I., RoJAS-VALENCIA, M. N. (2004): Destruction of helminth (Ascaris suum) eggs by ozone. Ozone Sci. Eng., 26: 359 - 366. DOI: 10.1080/01919510490482188 ÖZKAYHAN, M. A. (2006): Soil contamination with ascarid eggs in playgrounds in Kirikkale, Turkey. J. Helminthol., 80: 15 - 18. DOI: 10.1079/JOH2005311

Poglayen, G., Giannetto, S., Macri, B., Garippa, G., Scala, A., Cambosu, C., Giangaspero, A., Paoletti, B., Montauti, A. E., Traldi, G., Habluetzel, A. (2000): Canine zoonoses by environmental faecalization. Parassitologia, 42 (Suppl. 1): 220 - 222

Rinaldi, L., Biggeri, A., Carbone, S., Musells, V., Catelan, D., Veneziano, V., Cringoil, G. (2006): Canine faecal contamination and parasitic risk in the city of Naples (southern Italy). BMC Vet. Res., 2: 1 - 6. DOI: 10.1 186/1746-6148-2-29

Rojas-VAlencia, M. N., Orta-De-Velasquez, M. T., VACA-Mier, M., FrANCO, V. (2004): Ozonation by-products issued from the destruction of microorganisms present in wastewaters treated for reuse. Wat. Sci. Technol., 50: $187-193$

Stotharda J. R., Frenchb, M. D., Simba Khamisd, I., BAsÁnezB, M. G., RollinsonA, D. (2009): The epidemiology and control of urinary schistosomiasis and soiltransmitted helminthiasis in schoolchildren on Unguja Island, Zanzibar. Trans. R. Soc. Trop. Med. Hyg., 103: 1031 - 1044. DOI: 10.1016/j.trstmh.2009.03.024

Stott, R., Jenkins, T., BAHGAt, M., Shalaby I. (1999): Capacity of constructed wetlands to remove parasite eggs from wastewaters in Egypt. Wat. Sci. Tech., 40: 117-123 SZELAGIEWICZ-CZOSNEK, M. (1982): The role of soil fauna in the epizootiology of the pig ascaridosis. II Earthworm Lumbricus terrestris L. as a reserve host of Ascaris suum. Acta Parasitol. Pol., 20: 173 - 178

Takayanagui, O. M., Febronio, L. H., Bergamini, A. M., Okino, M. H., Silva, A. A., Santiago, R., Capuano, D. M., Oliveira, M. A., Takayanagui, A. M. (2000): Monitoring of lettuce crops of Ribeirao Preto, SP, Brazil. Rev. Soc. Brasil Med. Trop., 33: $169-174$

TARCZYNSKI, S. (1956): Studies on the morphology and developmental cycle of the European form of Strongyloides ransomi Schwartz et Alicata, 1930. Wiad. Parazyt. 2, $167-168$

Tavassoli, M., Hadian, M., Charesaz, S., Javadi, S. (2008): Toxocara spp. Eggs in Public Parks of Urmia City, West Azerbaijan Province Iran. Iranian J. Parasitol., 3: 24 $-29$

Trang, D. T., Mølbak, K., Cam, P. D., Dalsgaard, A. (2007): Helminth infections among people using wastewater and human excreta in peri-urban agriculture and aquaculture in Hanoi, Vietnam. Trop. Med. Int. Health, 12 suppl. 2: 82 - 90. DOI: 10.1111/j.1365-3156.2007.01945.x Xaviera, I. G. R., Ramosb, B. C., Santarém, V. A. (2010): Recovery threshold of Toxocara canis eggs from soil. Vet. Parasitol., 167: 77 - 78. DOI. 10.1016/j.vetpar. 2009.09.052.

Uga, S., J. Matsuo, J., Kimura, D., Rai, S.K., Koshino, Y., IGARASHI, K. (2000): Differentiation of Toxocara canis and Toxocara cati eggs by light and canning electron mi- 
croscopy. Vet. Parasitol., 92: 287 - 294. DOI: 10.1016/S0 304-4017(00)00323-x

Uhlikova, M., HuBner, J. (1998): Seroprevalence of Toxocara canis infection in Czech Republic. Cent. Eur. J. Public Health, 6: 195 - 198

Ulukanligil, M., SeyreK, A., Aslan, G., OzBilge, H., ATAY, S. (2001): Environmental pollution with soil-transmitted helminths in Sanliurfa, Turkey. Mem. Inst. Oswaldo Cruz, 96: 903 - 909. DOI: 10.1590/S0074-027620010007 00004

USEPA, 1993. United States Environmental Protection Agency. Part 503. Standards for the Use or Disposal of Sewage Sludge. 40 CFR Ch. I (7-1-93 Edition)

VAzQuez Tsuji, O., Martinez Barbarosa, I., TAYZavala, J., Ruiz Hernandez, A., Perez-Torres, T. A. (1997): Vegetables for human consumption as probable source of Toxocara spp. infection in man. Bolivian Chili Parasitol., 52: 47 - 50

RECEIVED FEBRUARY 1, 2011
Wharton, D. (1980): Nematode egg-shells. Parasitology, 81: $447-463$

WHO (2006): Guidelines for the Safe Use of Wastewater, Excreta and Greywater - Volume 3: Wastewater Use in Aquaculture. WHO, Geneva.

WiWAnitkit, V., WAENLOR, W. (2004): The frequency rate of Toxocara species contamination in soil samples from public yards in urban area "Payathai", Bangkok, Thailand. Rev. Inst. Med. Trop. S. Paulo, 46: $113-114$. DOI: 10.1590/S0036-46652004000200011

Yajima, A., Jouquet, P., Trung, D. D., Thi CAM, T.D., Tran C.D., Orange, D., Montresor, A. (2009): High latrine coverage is not reducing the prevalence of soiltransmitted helminthiasis in Hoa Binh province, Vietnam. Trans. R. Soc. Trop. Med. Hyg., 103: 237 - 241. DOI: 10.1016/j.trstmh.2008.08.012

ZIOMKO, I. (2006): Evaluation of manure impact of health of animals. Raporty PIB, 2: 87 - 96 